\title{
Potential Effect of PISA Equivalent Questions Using the Context of Aceh Traditional House
}

\author{
Uliyatul Usnul $^{1)}$, Rahmah Johar $^{1 *}$, Hizir Sofyan ${ }^{2)}$ \\ 1) Mathematics Education Department, Universitas Syiah Kuala, INDONESIA \\ ${ }^{2)}$ Mathematics Department, Universitas Syiah Kuala, INDONESIA \\ *Corresponding author: rahmah.johar@,unsyiah.ac.id
}

\begin{abstract}
The achievement of Indonesian students in PIS A remains unsatisfactory, as evidenced by their scores that are below the baseline level set in PISA. One of the contributing factors is that Indonesian students are less trained in solving problems with characteristics such as in PIS A items. Therefore, it is necessary to familiarize Indonesian students with PIS A equivalent problems, but the availability of these questions is still limited, especially concerning reasoning ability. In addition, the use of context is also crucial, especially the local contexts, which can help students understand mathematical phenomena from the perspective of their life experiences. The purpose of this study was to develop the questions of PISA equivalent mathematical reasoning ability using the context of Aceh traditional houses. This research used formative evaluation type development research from Tessmer. The results of this study were 12 mathematical questions equivalent to PIS A using the context of Aceh traditional house. The potential effect of the questions developed was analyzed based on the student's responses to the questionnaire, including two aspects: 1) students are interested and seriously working on the questions and 2) the students are interested in using the equivalent PIS A questions in the future.
\end{abstract}

Keywords: PIS A Equivalent Questions, Mathematical Reasoning Ability, Aceh Traditional House

Received: $29^{\text {th }}$ June 2019, Revised: $20^{\text {th }}$ August 2019, Accepted: $21^{\text {st }}$ August 2019

\section{Introduction}

The Programme for International Student Assessment (PISA) is an international study designed and organized by the Organization for Economic Cooperation and Development (OECD). PISA is held every three years, starting in 2000. The participants in the program are 15 years old students (Kemdikbud, 2016). PISA aims to assess the extent to which students have acquired knowledge and skills. The assessment focuses on competencies that are important for participating in modern society and relevant for lifelong learning (OECD, 2018). The basic competencies measured in PISA are reading, mathematics and science.

Indonesia has participated in the PISA since it was first held in 2000. The results of Indonesian students in PISA from 2000 to 2015 are lower than students in most countries. In PISA 2015, the score of Indonesian students was 386 and placed Indonesia in the order of 62 from 70 countries (OECD, 2016). The score is far behind the average score in PISA, 490. 
Many factors contribute to the low achievement of Indonesian students in the PISA test. One of them is that Indonesian students are unfamiliar in solving problems with characteristics such as in PISA questions (Purmono \& Dafik, 2015). In addition, the characteristics of questions given by the teacher in the classroom are routine and rarely associated with everyday life (Mansur, 2018). One method to overcome the low achievement of Indonesian students in the PISA test is to familiarize students with solving PISA model questions in the classroom.

There are seven basic mathematical abilities used in the assessment of mathematics performance in PISA, one of which is reasoning and argument ability (OECD, 2010). Reasoning ability is one of the standard components in mathematics learning besides problem-solving, representation, communication and connection skills (Ramdani, 2012). Problem-solving in mathematics cannot be separated from reasoning. Therefore, a person who has good reasoning ability will be able to solve mathematics problems well (Sroyer, 2013).

The poor performance of Indonesian students in PISA test indicates that they have not been able to develop their mathematical reasoning abilities (Wardani \& Rumiati, 2011). Junior high school students rarely solve PISA-like problem. They have not been able to reason with the information received and to provide reasons for each step in solving the problems (Aini, 2014). In addition, the teachers often face the challenge of the limited designed questions available to accord with the students' potential and characteristics. Consequently, the students' potential to use their reasoning ability to solve the problem have not been developed optimally (Martani, 2016).

The questions equivalent to PISA, especially those that are oriented to daily life, are necessary to develop students' reasoning ability and to familiarize students with PISA questions. The questions designed are expected to be able to help teachers to enrich their variety of mathematics questions given to students.

The learning process of mathematics needs to be linked to contextual problems in society, not only those experienced by students but also various cultures around Indonesia and the world (Wardhani and Rumiati, 2011). Thus, students' are expected to have broad insights and recognize their culture so that they can solve the problems that arise around them.

The Cornerstone of Tech Prep (as cited by Charmila, Zulkardi \& Darmawijoyo, 2016) stated that a learning using context could encourage students to find meaningful relationships between abstract ideas and practical applications in real-world contexts. Besides, Gravemeijer \& Doorman (1999) argued that context plays an essential role as a starting point for students to explore mathematical ideas in various real situations. Widjaja (2013) added that context is not only outer clothing of mathematics but how the students have the ability to produce multiple mathematical interpretations and strategies in solving problems. Susanti (2016) also believes that the use of local contexts can help students understand mathematical phenomena from the perspective of their life experiences. Therefore, the researcher assumed that the development of contextual mathematical questions related to daily life and the environment where students live is appealing to promote the students reasoning ability in learning.

Some studies have been carried out on the development of equivalent PISA questions using local context in Indonesia. Putra (2015) studied the development of PISA questions using Lampung context. Charmila (2016) has also conducted research on the development of mathematical questions in PISA model using the Jambi context. While Hardianti (2018) used Palembang context to develop PISA type problems. These previous studies showed that many researchers considered the necessity of developing PISA model problems. 
In Aceh, Maqshum (2017) has conducted a study on the development of problemsolving skills and mathematical communication equivalent to PISA in the Aceh context. In addition, Marwanda (2017) has also researched on the development of PISA equivalent questions to improve students' communication skills and mathematical problem-solving. However, there is no research developed a PISA equivalent problem, focusing on the context of the Aceh traditional houses. Aceh traditional house architecture is closely related to mathematics topics, such as geometry, number patterns, and algebra.

Based on the description above, this research aimed to explore the wisdom of local culture in the form of Aceh traditional houses, represented in mathematical questions equivalent to PISA. It is also to increase students' interest in learning mathematics and help students understand the questions given. Thus, the research question in this study is that how is the potential effect of PISA equivalent mathematical reasoning ability questions using the context of Aceh traditional house?

\section{Research Methods}

This research is formative evaluation research or development, as developed by Tessmer (1993). He argued that the formative evaluation stage includes expert review and one-to-one (low resistance to revision), small groups and high resistance in revision. Figure 1 presents the illustration of the formative evaluation stages.

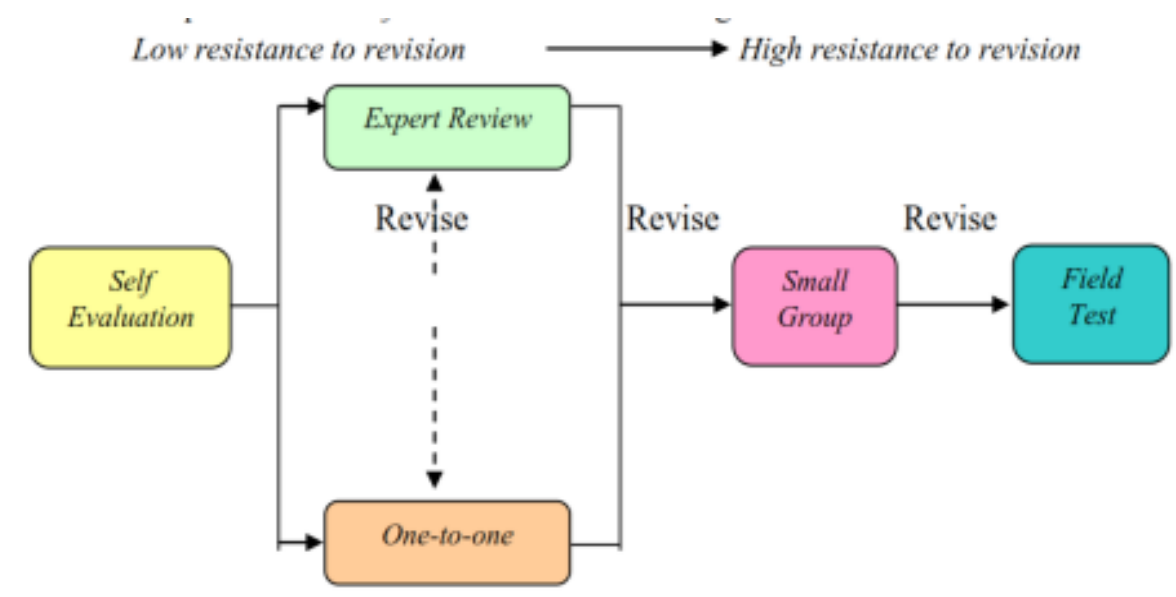

Figure 1. The Flow of Formative Evaluation Tessmer (1993)

In the self-evaluation stage, an assessment was undertaken by the researchers on the equivalent PISA questions developed. This stage began by preparing and designing PISA equivalent questions. The formative evaluation stage consisted of four stages. They are 1) the expert review stage to examine the validity of the questions; 2) the one-to-one stage; 3) the small group stage to investigate the readability of the questions by students; and 4) the field test stage to test the practicality and potential effects of the questions. The subjects in this study were Year 9 students following PISA criteria, children up to 15 years old.

This study was conducted in four stages of testing, employing different research subjects in each stage. In the one-to-one trial phase, the research subjects were three students. Besides, six students participated in the small group stage. Next, the research subjects at the stage of the field test (field trials) consisted of 60 students. In addition, before conducting the field test, the researcher conducted an expanded trial to examine the validity and reliability of the questions. The instrument used in this study was student questionnaires concerning the questions developed. 


\section{Results and Discussion \\ Preliminary}

The results of the preliminary stage are based on the identification and analysis of learning materials taught for junior high schools based on the 2013 curriculum, including algebra, plane geometry, solid geometry, and so on. The mathematical reasoning indicators, to design the problems, were also formulated in this stage. Among various indicators of mathematical reasoning ability by experts, the indicators formulated by NCTM (2000) were used because they are applicable internationally.

This stage also conducted an analysis of PISA questions based on the PISA released items from 2006 to 2012 and the Mathematics Literacy Contest questions between 2011 and 2016. The results showed the characteristics of the PISA items domain, where PISA questions have specific content, context and process. The contents in PISA are changes and relationships, space and shape, quantity, and uncertainty and data. The context in PISA consists of personal, occupational, and scientific, while the process in PISA includes formulating, employing, and interpreting.

In this stage, the authors identified and analyzed the variety of traditional Acehnese houses related to mathematics learning. The results included the information on the architecture of Aceh traditional houses associated to the building, the culture of constructing Aceh traditional houses related to algebra, and so on.

In addition, the authors also compiled and designed questions of PISA equivalents with the context of Aceh traditional houses based on the information from the curriculum analysis stage; the formulation of mathematical reasoning ability indicators; the analysis of PISA questions; and the analysis and identification of the different contexts of Aceh traditional houses. This stage produced a set of questions (13 items), called the first prototype consisting of drafts and rubrics concerning mathematical reasoning ability equivalent to PISA with the context of Aceh traditional houses. In term of the contents, the prototype comprised six questions of space and shape, four questions of quantity, and three questions of change and relationships. In relation to the context, the questions consisted of eight social, four personal, and one occupational questions. Concerning the process, the questions included ten questions of employing, two questions of interpreting, and one question of formulating.

\section{Expert Review}

Based on the validator's assessment, it was concluded that the questions of PISA equivalent mathematical reasoning ability using the context of Aceh traditional houses had generally met the validity indicators in terms of content, constructs, and language. However, there was one question considered invalid. So, the first prototype required revision based on the validators' comments and suggestions. The revised results were called the second prototype, consisting of 12 items.

\section{One-to-one}

In this stage, students were asked to read and comment on the questions. These activities aimed to examine the readability of the questions based on the students' responses and comments on each item. They were then taken into consideration for the revisions made to the second prototype. The revised results of this stage were called the third prototype.

\section{Small Group}

At this stage, six students were chosen with different levels of ability. The six students wrote the answer on the sheet provided. In addition to the written answers, the students were also asked to comment on each question. Students' answers and 
comments at this stage would be subject to revision. The revised results were called the fourth or final prototype.

\section{Field Test}

At this stage, the instrument for the final prototype was also tested on 60 Year 9 students in one of the public junior high schools in Banda Aceh. The students were at varying ability level. In solving the problem, students were asked to write the appropriate strategy. The results of this stage were the student answer sheets and student responses to the questionnaire. This stage focused on exploring the potential effects of the questions developed.

The final prototype produced in this study was twelve questions about PISA equivalent mathematical reasoning ability using Aceh traditional house contexts. These questions consisted of five questions about space and shape, four questions about quantity, and three questions about change and relationship. Concerning the mathematical context in PISA, the questions consisted of seven societal, four personal, and one occupational contexts. In addition, based on the mathematical process, these questions comprised nine questions of employing, two of interpreting and one of formulating. In term of the prediction of the question level, the questions were classified as level 3 (three questions), level 4 (seven questions), and level 5 (two questions). Table 1 shows a mapping of the questions developed.

Table 1. Mapping of PISA Equivalent Mathematical Reasoning Ability Questions

\begin{tabular}{clllc}
\hline \multirow{2}{*}{ QN } & \multicolumn{3}{c}{ PISA DOMAIN } & Question Level \\
\cline { 2 - 4 } & \multicolumn{1}{c}{ Content } & Context & Process & in PISA \\
\hline 1 & Space and Shape & Societal & Employ & Level 3 \\
2 & Space and Shape & Societal & Employ & Level 4 \\
3 & Quantity & Personal & Employ & Level 4 \\
4 & Space and Shape & Societal & Interpret & Level 4 \\
5 & Space and Shape & Societal & Employ & Level 4 \\
6 & Quantity & Societal & Employ & Level 4 \\
7 & Change and relationship & Personal & Interpret & Level 5 \\
8 & Quantity & Societal & Employ & Level 4 \\
9 & Space and Shape & Personal & Employ & Level 3 \\
10 & Change and relationship & Occupational & Employ & Level 5 \\
11 & Change and relationship & Personal & Employ & Level 4 \\
12 & Quantity & Societal & Formulate & Level 3 \\
\hline
\end{tabular}

Furthermore, the discussion concerning students' answers in the field test stage focused on questions 7 (Figure 2) and 11 (Figure 4), because the students were able to solve them correctly. As for the remaining questions, many students had incorrect answers.

The first question discussed was question 7 concerning the rules for visiting the Acehnese cultural customs. The question developed was expected to promote student's mathematical literacy related to Acehnese culture. This problem is open-ended, where students can choose the number of steps to be used, 7 or 9. Thus, students can apply their reasoning abilities to solve this problem. 


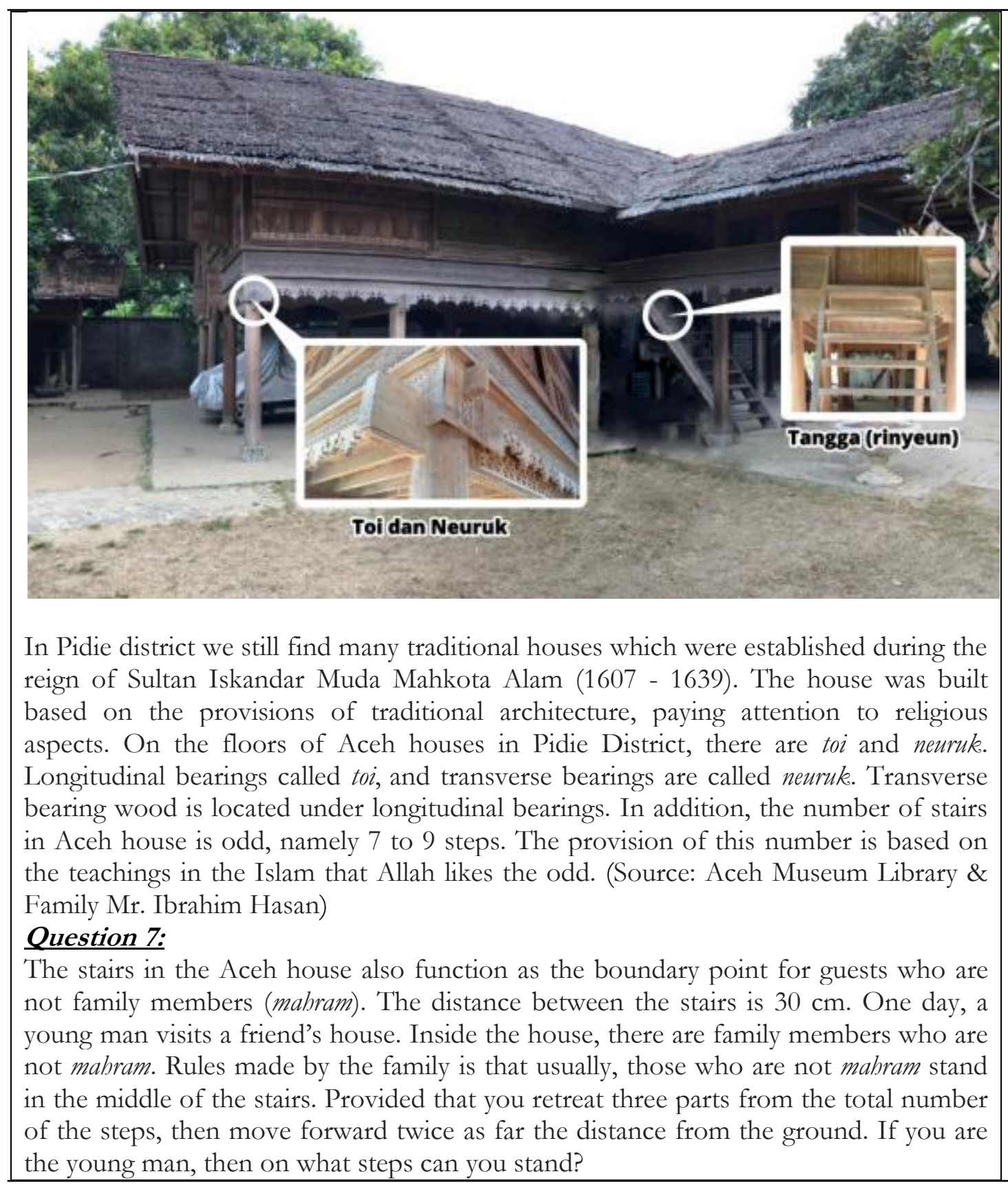

Figure 2. Problem 7

The problem in Figure 2 was developed to stimulate the students' reasoning abilities. The reasoning started by choosing the number of steps to be used, then determined half the number of steps. The results of the second step in solving this problem were influenced by the number of steps selected. So, the guest standing point would be affected by the number of steps in the house. Figure 3 describes one of the students' answers to question 7. 


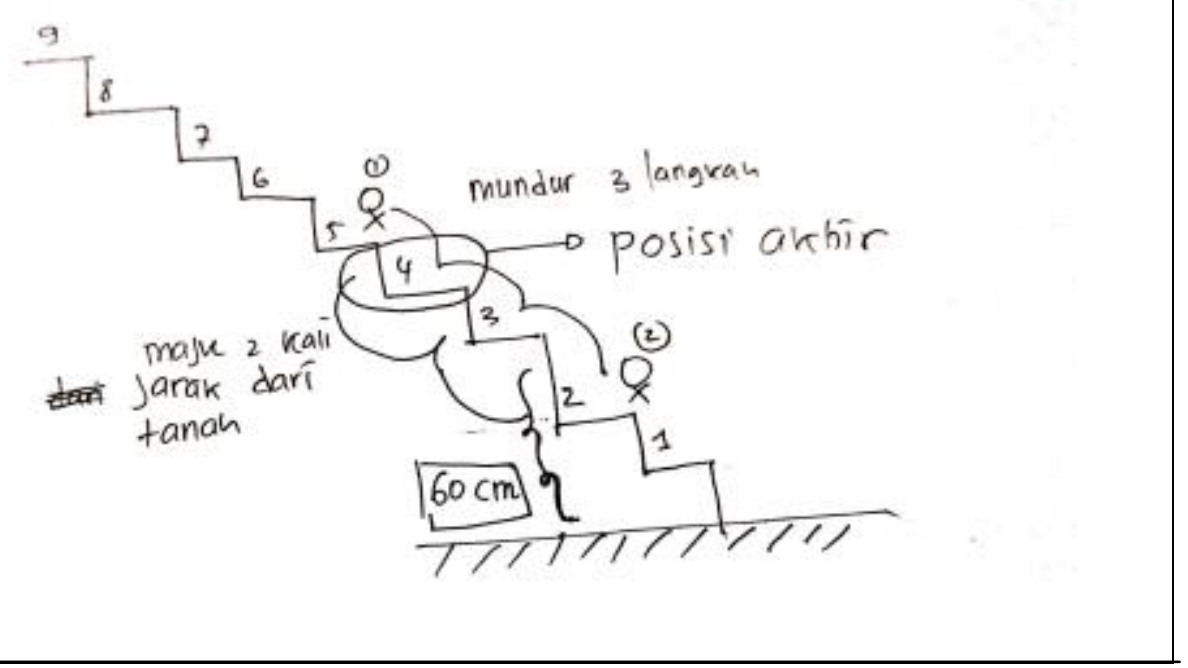

Figure 3. One of the student's answer to problem 7

The student's answers in Figure 3 involved high reasoning and argumentation. Here, students only used an illustration in solving the problem. The student did not use symbols when answering the question, and they used the reasoning strategy arranged by themselves. The students involved critical thinking processes that were choosing relevant information or ideas, making connections between information or ideas, reconnecting with relevant information or ideas, and reconnecting with previous problems (Kurniasih, 2011).

The next problem discussed was question 11, as shown in Figure 4. The problem used the context of the Krong Pade in every traditional Aceh house. The ability used in solving the problem was a mathematical reasoning ability to determine the volume of the Krong Pade and the number of days needed to empty the Krong Pade, and to predict when the Krong Pade should be refilled. Figure 5 shows one of the student's answers for solving problem 11.

Students' answers, as shown in Figure 5, involved reasoning and argumentation in solving the problem. After determining the volume of Krong Pade, students listed the number of days each year. This strategy is in accordance with the indicator of reasoning, that is making statements and finding conclusions in solving a problem (Boesen, 2010). Unfortunately, the student made a mistake in counting the number of days each year. The student also did not pay attention to the leap year, so that the score was not maximum. In the interview, the student stated that he was in a hurry, so the answer was not optimal. The average score of 60 students in solving the problems developed by referring the scores in PISA is presented in Table 2.

Table 2 indicates most students were below level 1 and less than $2 \%$ of students could reach level 4. Besides, none of the students had been able to reach level 5 and 6 . It can be concluded that the students could not work in complex situations and solve complex problems (level 5). The students were not able to use their reasoning in solving mathematical problems (level 6). This results support the fact that most of the Indonesian students can only work on the level 3 or below PISA model problems, and none of the students can reach level 5 and 6 (OECD, 2013).

Besides the student answer sheets, the questionnaires of the students' responses can be used to determine the potential effects of the questions developed. According to Guskey (as cited by Zulkardi, 2002), potential effects can be seen from the level of effectiveness of the development including reactions given by subjects (participants or pupils) and the use of new knowledge and skills by the students. Table 3 shows the 
results of students' responses in the field test stage, as seen from two aspects: the attraction and seriousness, and the intention to continue using PISA equivalent questions.

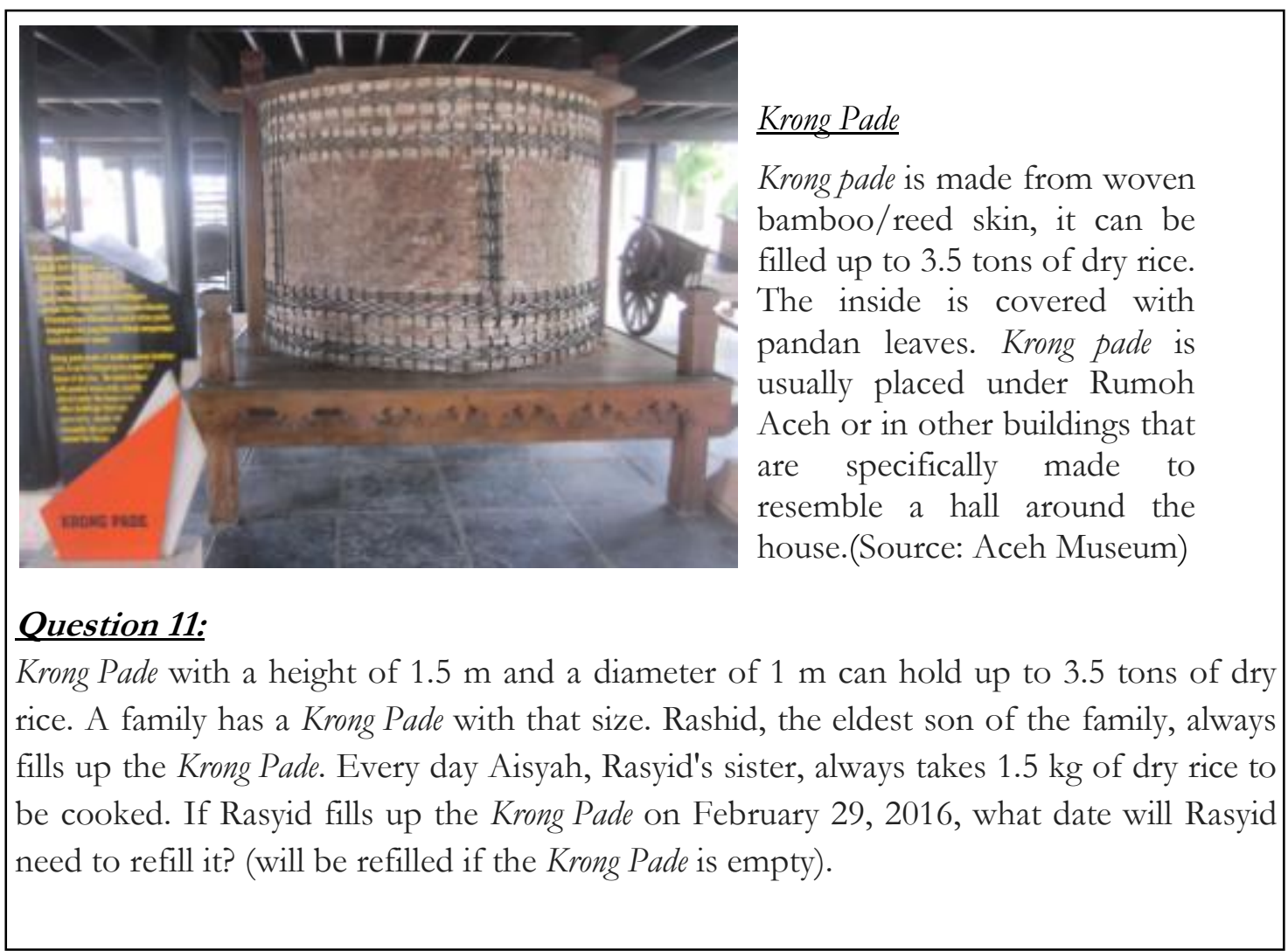

Figure 4. Problem 11

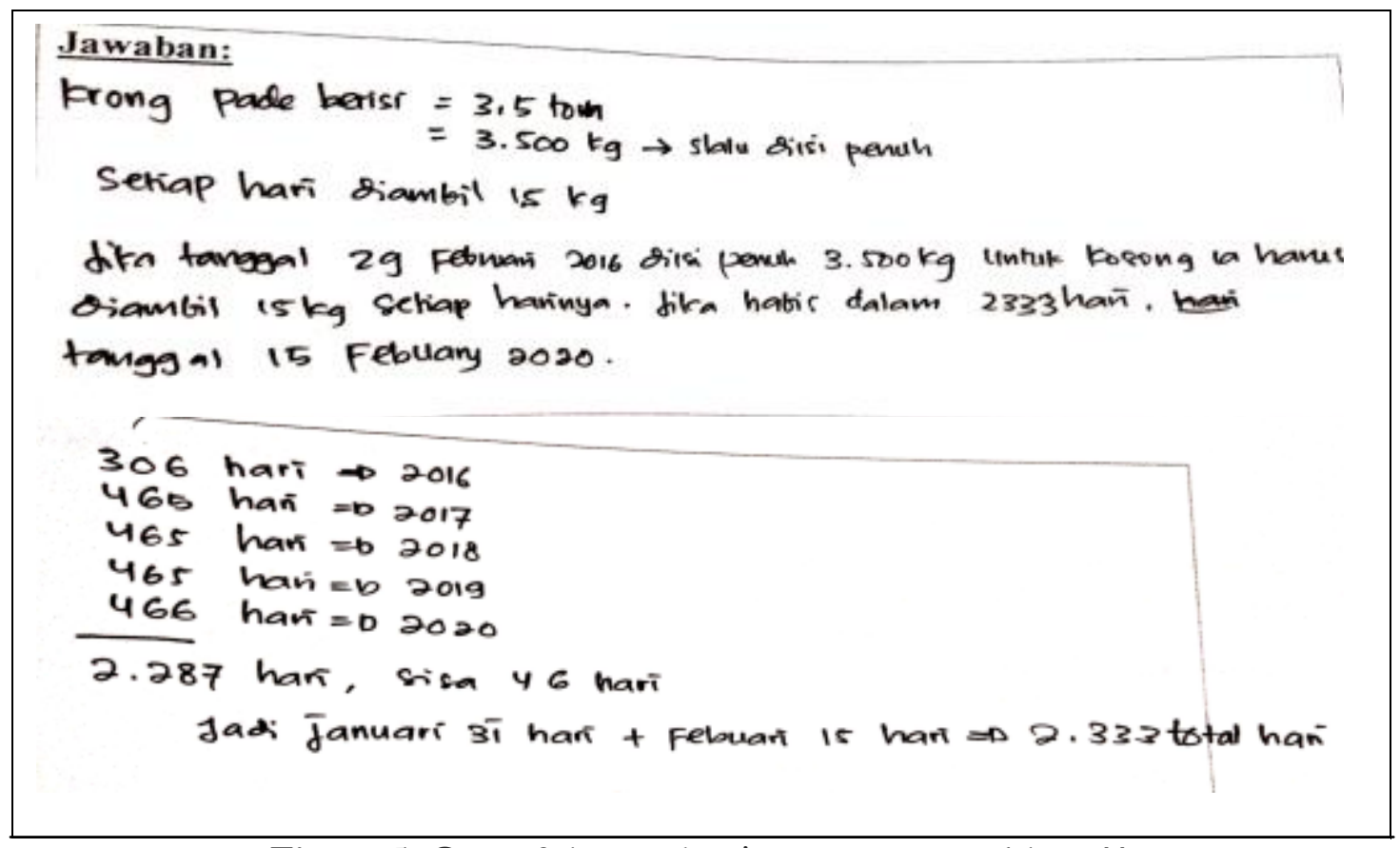

Figure 5. One of the student's answer to problem 11 
Table 2. Distribution of Average Scores in the Field Test stage

\begin{tabular}{cccc}
\hline Value Interval & Frequency & Percentage & Level (in PISA) \\
\hline $\mathrm{x}>669$ & 0 & $0 \%$ & Level 6 \\
$607<\mathrm{x} \leq 669$ & 0 & $0 \%$ & Level 5 \\
$544<\mathrm{x} \leq 607$ & 1 & $1,7 \%$ & Level 4 \\
$480<\mathrm{x} \leq 544$ & 1 & $1,7 \%$ & Level 3 \\
$420<\mathrm{x} \leq 480$ & 3 & $5 \%$ & Level 2 \\
$358 \leq \mathrm{x} \leq 420$ & 4 & $6,6 \%$ & Level 1 \\
$\mathrm{x}<358$ & 51 & $85 \%$ & $<$ Level 1 \\
Total & 60 & $100 \%$ & \\
\hline
\end{tabular}

Table 3. Percentage of Student Response to PISA Equivalent Questions

\begin{tabular}{|c|c|c|c|}
\hline Aspect & Statement & Frequency & $\begin{array}{l}\text { Percentage } \\
\text { of Student } \\
\text { Responses }\end{array}$ \\
\hline \multirow{4}{*}{$\begin{array}{l}\text { Interest } \\
\text { and } \\
\text { seriousness }\end{array}$} & $\begin{array}{l}\text { Students are interested and serious in solving } \\
\text { all the questions provided }\end{array}$ & 8 & $13.3 \%$ \\
\hline & $\begin{array}{l}\text { Students are only interested and serious in } \\
\text { working on certain questions }\end{array}$ & 31 & $51,7 \%$ \\
\hline & $\begin{array}{l}\text { Students are interested, but not serious in } \\
\text { doing all the questions }\end{array}$ & 14 & $23,3 \%$ \\
\hline & $\begin{array}{l}\text { Students are not interested in doing all the } \\
\text { questions }\end{array}$ & 7 & $11,7 \%$ \\
\hline \multirow{2}{*}{$\begin{array}{l}\text { Desire to } \\
\text { use PISA } \\
\text { equivalent } \\
\text { questions }\end{array}$} & $\begin{array}{l}\text { In learning mathematics, the students want } \\
\text { the teacher to give them the questions } \\
\text { similar to the questions presented by the } \\
\text { researcher }\end{array}$ & 31 & $51,7 \%$ \\
\hline & $\begin{array}{l}\text { In solving a mathematics problem, students } \\
\text { want to answer the questions using the same } \\
\text { process as the question provided by the } \\
\text { researcher }\end{array}$ & 29 & $48,3 \%$ \\
\hline
\end{tabular}

Based on Table 3, the aspects of students' interest and seriousness can be categorized as positive. It can be seen that most of the students (approximately 65\%) were interested and serious in solving the questions given by the teacher. Although some of them only interested and serious in certain questions. The results are in line with the research conducted by Widjaja (2013), reporting that the use of context, in particular, the cultural context, is critical to motivating students in learning mathematics. Increasing student motivation will improve learning outcomes.

Furthermore, the aspect of the desire to continue using the equivalent PISA questions was also investigated. Approximately $50 \%$ of students wanted to work on a question similar to the items developed. They were also interested in solving math problems with the same process as the questions given by the researcher. Although the students' ability has not reached level 5 and 6, students are interested in solving the PISA equivalent questions. The result of this study is in line with Buang (2015), arguing that culture is the ability of an individual to use strength, energy, and reason towards increasing the mind's intelligence to deal with a problem. 
Furthermore, several students were interviewed based on their responses to the questionnaire. The following are the interview excerpts.

\begin{tabular}{|c|c|c|}
\hline Researcher (R) & : & Have you ever had a problem like this before? \\
\hline Student A & : & $\begin{array}{l}\text { I saw it once, when I joined the mathematical Olympiad in elementary } \\
\text { school first }\end{array}$ \\
\hline Student B & : & Never \\
\hline $\mathrm{R}$ & : & Which questions do you find difficult? \\
\hline Student A & : & $\begin{array}{l}\text { In my opinion, problem } 8 \text { is the most difficult, I understand the meaning of } \\
\text { the problem, but I am confused about how to imagine it, especially how the } \\
\text { shape of the sago palm leaves sewn using rattan }\end{array}$ \\
\hline Student B & $:$ & I think almost everything is difficult because I don't know how to do it \\
\hline $\mathrm{R}$ & : & In the future, are you interested in solving questions like this? \\
\hline Student A & $:$ & $\begin{array}{l}\text { Yes, I am, moreover, I can obtain additional information that I didn't get } \\
\text { at school, for example, the number of traditional houses in Aceb }\end{array}$ \\
\hline Student B & : & $\begin{array}{l}\text { Yes, I am, but I still could not answer the questions, because I didn't } \\
\text { understand the stories like this, but I found out about the Aceb traditional } \\
\text { house on the question that was shared earlier. }\end{array}$ \\
\hline $\mathrm{R}$ & : & $\begin{array}{l}\text { Among the problems you bave worked on, which one do you think is the } \\
\text { easier? }\end{array}$ \\
\hline Student A & : & $\begin{array}{l}\text { There are some questions that I find easy, namely questions number 1, 6, 9, } \\
\text { and } 12\end{array}$ \\
\hline Student B & : & In my opinion, number 1 is the easiest \\
\hline $\mathrm{R}$ & : & $\begin{array}{l}\text { Finally, what is your response or comment on the overall PISA questions } \\
\text { that were given? }\end{array}$ \\
\hline Student A & $:$ & $\begin{array}{l}\text { In my opinion, the question given is interesting. Although there is something } \\
\text { I can't do, it makes me curious about how to solve it }\end{array}$ \\
\hline Student B & : & $\begin{array}{l}\text { The problem is that it's very hard. Although I could solve some of them, } \\
\text { there were more that I could not solve }\end{array}$ \\
\hline
\end{tabular}

The results of the questionnaire responses and students' interviews showed that the questions developed in this study could encourage the students to be interested and serious in solving the questions. The results of the questionnaire indicated that the students gave a positive response to the problem developed. The positive responses of students are in line with the level of effectiveness of the development of the student reaction as stated by Geskey (as cited by Zulkardi, 2002). All forms of responses or positive reactions of students are potential effects of the questions developed. The positive responses from students, as evidenced by their interest and seriousness is indeed inseparable from the use of the Aceh traditional house context.

The results of this study support the evidence of the importance of using contexts that are familiar to students to improve the conducive atmosphere of mathematics learning as well as students' mathematical abilities. The study of Mardayanti, et al. (2016) showed that questions developed using context have a potential effect on student test results, where it is seen from the diversity of the students' answers on the questions provided. Moreover, Apriyani, et al. (2017) also stated that using context in learning can have potential effects, where students find it easy to understand the learning provided. Widada, et al. (2018) used the Bengkulu context in learning to improve students' 
cognitive level. Their research showed that the mathematical understanding of students taught using learning-based context was higher than those taught using the conventional method. Furthermore, Simamora, et al. (2018) and Ulandari, et al. (2019) used Batak context to improve students' mathematical problem solving abilities and self-efficacy. Simamora integrated the context in their learning strategy. On the other hand, Ulandari developed the learning materials based on context.

\section{Conclussion}

The question of PISA equivalent mathematical reasoning ability using the context of Aceh traditional house developed had a potential effect. Most of the students were interested in solving the equivalent PISA questions given. In addition, most of the students were willing to work on the similar questions like the ones developed rather than the usual problems presented in class.

\section{Bibliography}

Aini, R.N. (2014). Analisis Pemahaman Siswa SMP dalam Menyelesaikan Masalah Aljabar pada PISA. Jurnal MATHEdunesa, 3(2), 158 - 164.

Apriyani, R., Somakim, S., \& Darmawijoyo, D. (2017). Developing Teaching Material of Direct Proportion Based on Agricultural Context. Jurnal Kependidikan: Penelitian Inovasi Pembelajaran, 1(1), 38-49.

Buang, N.A. (2015). Komunikasi Budaya Melalui Pendidikan? Atau Pendidikan untuk Komunikasi Budaya?.Proceedings of ACER-N I Meeting and Seminar Fakultas Pascasarjana Universitas Pasundan, 1 - 4.

Boesen, J.L. (2010). The Relation Between Types of Assessment Task and The Mathematical Reasoning Students Use. Educational Studies in Mathematics, (75), 89 105.

Charmila,N., Zulkardi., \&Darmawijoyo. (2016). Pengembangan Soal Matematika Model PISA Menggunakan Konteks Jambi. Jurnal Penelitian dan Evaluasi Pendidikan, 20(2), $198-207$.

Gravemeijer, K., \& Doorman, M. (1999). Context Problems in Realistic Mathematics Education: A Calculus Course as an Example. Educational Studies in Mathematics, 39, $111-129$.

Johar, R. (2012). Domain Soal PISA untuk Literasi Matematika. Jurnal Peluang, 1(1), 30 41.

Kemdikbud.(2016). Peringkat dan Capaian PISA Indonesia Mengalami Peningkatan. https://www.kemdikbud.go.id/main/blog/2016/12/peringkat-dan-capaian-pisaindonesia-mengalami-peningkatan. Diaksestanggal 09 Mei 2019.

Kurniasih, A. W. (2011). Identification Critical Thinking Stages of Students'Mathematics Education Study Program FMIPA UNNES for Solving Mathematics Problems. In the Fourth National Conference on Mathematics Education, P(63), 639 - 650.

Lithner.J. (2012). Mathematical Reasoning in Teacher's Presentation. The Jurnal of Mathematical Behavior,JAI, $252-269$.

Mansur, N. (2018). Melatih Literasi Matematika Siswa dengan Soal PISA. Prosiding Seminar Nasional Matematika I Universitas Negeri Semarang, 140 - 144.

Mardayanti, E., Zulkardi, Z., \& Santoso, B. (2016). Pengembangan Soal Open-Ended Menggunakan Konteks Sumatera Selatan Materi Sistem Persamaan Linear Dua Variabel Kelas X SMA. Jurnal Pendidikan Matematika Sriwijaya, 10(1), 1-14.

Martani, B.T \&Murtiyasa.(2016). Pengembangan Soal Model PISA Pada Konten Quantity Untuk Mengukur Kemampuan Penalaran Matematis Siswa. Prosiding Seminar Nasional Pendidikan Matematika Universitas Muhammadiyah Surakarta, $1-10$. 
Marwanda, T. (2017). Pengembangan Soal Setara PISA untuk Meningkatkan Kemampuan Komunikasidan Pemecahan Masalah Matematis Siswa. Tesis. Pascasarjana UniversitasSyiah Kuala. Tidak Diterbitkan.

Maqshum, A. (2017). Pengembangan Soal Kemampuan Problem Solving dan Komunikasi Matematis Setara PISA dengan Menggunakan Konteks Aceh. Tesis. Pascasarjana Universitas Syiah Kuala. Tidak Diterbitkan.

OECD. (2010). PISA 2009 Result: What Student Know and Can Do-Student Performance in Reading, Mathematics and Science. USA: OECD-PISA.

OECD. (2013). PIS A 2012 Results: Ready to Learn Students' enggagement and self-beliefs (Volume III).

OECD. (2016). PISA 2015 Result Excelence and Equity in Education (Volume I). Paris: OECD Publishing.

OECD. (2018). PIS A 2018: Information About The PIS A Study 2018. Le Gouvernement, Luxembourg.

Purnomo, S \& Dafik. (2015). Analisis Respon Siswa Terhadap Soal PISA Konten Shape and Space dengan Rasch Model. Jurnal Seminar Nasional Matematika dan Pendidikan, $P M(163), 1155-1160$.

Putra, Y.Y., Zulkardi.,\&Hartono,Y. (2016). Pengembangan Soal Matematika Model PISA Level 4, 5, 6 Menggunakan Konteks Lampung. Jurnal Kreano, 7(1), 10 - 16.

Ramdani, Y. (2012). Pengembangan Instrumen dan Bahan Ajar Untuk Meningkatkan Kemampuan Komunikasi, Penalaran, dan Koneksi Matematis dalam Konsep Integral. Jurnal Penelitian Pendidikan, 13(1), 44 - 52.

Simamora, R. E., \& Saragih, S. (2018). Improving Students' Mathematical Problem Solving Ability and Self-Efficacy through Guided Discovery Learning in Local Culture Context. International Electronic Journal of Mathematics Education, 14(1), 6172.

Sroyer, A. (2013). Penalaran Kuantitatif (Quantitatif Reasoning) dalam Pemecahan Masalah Matematika. Prosiding Seminar Nasional Matematika dan Pendidikan Matematika Universitas Negeri Yogyakarta, $P(6), 39$ - 44.

Susanti, E. (2016). Pengembangan Soal Matematika Tipe TIMSS Menggunakan Konteks Rumah Adat Untuk Siswa Sekolah Menengah Pertama. Jurnal Pendidikan Matematika, 10(2), 1 - 21.

Tessmer, M. (1993).Planning and Conducting Formative Evaluation. London: Kogan Page.

Ulandari, L., Amry, Z., \& Saragih, S. (2019). Development of Learning Materials Based on Realistic Mathematics Education Approach to Improve Students' Mathematical Problem Solving Ability and Self-Efficacy. International Electronic Journal of Mathematics Education, 14(2), 375-383.

Wardhani, S \&Rumiati. (2011). Instrumen Penilaian Hasil Belajar Matematika SMP: Belajar dari PISA dan TIMSS (Modul Matematika SMP Program Bermutu). Yogyakarta: PPPPTK Matematika.

Widada, W., Herawaty, D., \& Lubis, A. N. M. T. (2018, September). Realistic mathematics learning based on the ethnomathematics in Bengkulu to improve students' cognitive level. In Journal of Physics: Conference Series (Vol. 1088, No. 1, p. 012028). IOP Publishing.

Widjaja, W. (2013). The Used of Contextual Problem Support Mathematical Learning. Journal on Mathematics Eduacation, 4(2), 151 - 159.

Zulkardi. (2002). Developing a Learning Environment on Realistic Mathematics Education for Indonesian Student Teachers. Enschede: Print Partners Ipskamp. 